Aneta Jarzębińska*

ORCID: 0000-0001-5765-8741

Szczecin, Poland

\title{
Prisoners' Alienation and Lack of Contact with Relatives
}

\section{Wyobcowanie osób odbywających karę pozbawienia wolności z kontaktów z bliskimi}

\begin{abstract}
No studies have examined contacts between incarcerated persons and their relatives, as well as the forms of those contacts. To learn about these subjects, a survey study was conducted in five penitentiaries, among 478 male inmates. Furthermore, the impact of recidivism on the aforementioned structure of contacts with relatives has been studied. It was determined that most of the incarcerated males had contact with their relatives, usually in the form of phone conversations. The source of those contacts was usually the mother of the prisoner. The percentage of prisoners who maintained contact with at least one relative was higher among those participants who were serving their first sentence, in comparison to repeat criminals. However, when the population of repeat criminals was grouped by the number of served sentences in the penitentiary (two, three, four or more served sentences), it became apparent that prisoners who were imprisoned for the third time constituted the highest percentage of prisoners who had contact with relatives, among the repeat criminals. The change of structure in the source and forms of contact with relatives, which correlated with the increase of served sentences, was noted. The number of
\end{abstract}

* Dr. Aneta Jarzębińska, Assistant Professor, Institute of Pedagogy, University of Szczecin; email: anetajarzebinska@interia.pl. 
prisoners who declared contact with their mothers, fathers and wives decreased, while the percentage of prisoners who had contact with their partners was relatively stable. However, an increase in the contacts with their offspring (only through phone calls) was noted. Ultimately, it has been shown that the percentage of persons who stay in contact with at least one person outside prison is highest among those serving their first sentence and lowest among repeat criminals; and that repeat criminals have the fewest sources and forms of contact among all of the subpopulations distinguished in the study.

Keywords: situational alienation; imprisonment; contact between the imprisoned and the outside world.

Abstrakt: W Polsce nie istnieją badania na temat tego, z kim spośród bliskich kontaktują się skazani oraz jakie formy przybierają te kontakty. Poznanie tych faktów było celem badania ankietowego, w którym uczestniczyło 478 mężczyzn odbywających karę pozbawienia wolności w jednym z pięciu zakładów penitencjarnych. Zbadano również, jak na strukturę kontaktów skazanych z bliskimi wpływa recydywa penitencjarna. Ustalono, że większość uwięzionych mężczyzn miała kontakt z bliskimi, zwykle w formie rozmów telefonicznych, oraz że źródłem tych kontaktów najczęściej była matka. Odsetek utrzymujących kontakt z przynajmniej jedną bliską osobą był wyższy dla uczestników badania, dla których aktualny pobyt w zakładzie karnym był pierwszym niż dla recydywistów penitencjarnych. Kiedy jednak pogrupowano populację recydywistów w zależności od liczby pobytów w zakładzie karnym (dwa, trzy oraz cztery i więcej pobytów) okazało się, że najwyższy odsetek posiadających kontakt $\mathrm{z}$ bliskimi odnotowano $\mathrm{w}$ subpopulacji pozbawionych wolności po raz trzeci. Zauważono, że wraz ze wzrostem liczby pobytów w zakładzie karnym zmieniała się struktura źródeł i form kontaktów z bliskimi. Zmniejszyła się liczba skazanych deklarujących kontakt z matką, ojcem i żoną. Względnie stabilny był odsetek utrzymujących kontakt z partnerką, natomiast wzrost odnotowano w odniesieniu do kontaktów z potomstwem, co jednak dotyczyło wyłącznie rozmów telefonicznych. Ostatecznie wykazano, że odsetek posiadających kontakt z choćby jedną osobą na wolności jest najwyższy wśród odbywających wyrok po raz pierwszy, a najniższy wśród multirecydywistów, oraz że multirecydywiści mają najmniej źródeł i mniej form kontaktu ze wszystkich wyróżnionych w badaniu subpopulacji.

Słowa kluczowe: wyobcowanie sytuacyjne; kara pozbawienia wolności; kontakty osób pozbawionych wolności ze światem zewnętrznym. 


\section{Introduction}

Many research papers have been created to study the concept of 'alienation', such as those of Seeman (1959), Kmiecik-Baran (1988, 1993, 1995) and Korzeniowski $(1986,1990)$, which discussed the Polish aspect of the issue. Furthermore, this topic has been researched by Niewiadomska (2009) and Niewiadomska and Chwaszcz (2010). When reading the aforementioned works, one might consider that the interpretation of alienation depends on the cognitive context of the interpreter. On the one hand, alienation can be considered as a psychological category, and compared with mindsets based on individualism and subjectivity, as well as in terms of expectations with regard to life. On the other hand, alienation can also be analysed with structural conditions of social life in mind (Czerwińska-Jakimiuk, 2013, pp. 359-361), as a characteristic of the situation rather than the subject. At the same time, the perception of a given area of outside reality and its subjective evaluation can lead a person to the realisation that he or she is detached or disconnected from it. This realisation or feeling is professionally known as 'alienation' (Kmiecik-Baran, 1995, p. 17).

A classic example of structural alienation is being incarcerated in a prison. From the moment a person is imprisoned, he or she is disconnected from the source of many sensory stimuli; and, more importantly, from the culture and society in which that person has functioned so far. From that moment, such a person has to obey the administrative decision which compels him or her to stay with a group of inmates, who sometimes are vastly different from themselves, both in terms of their behaviour and personality. This facilitates the process of becoming a part of the informal life of a prison (Luczak, 2012, p. 41). Furthermore, the structure of contact between the imprisoned and their relatives outside also changes. The form, time and frequency of such contacts are being regulated, which can lead to being disconnected from reality. Such a situation can lead to a feeling of alienation, a phenomenon which risks the development of the following negative personality traits: an irrational judgment system, lack of forward thinking, being susceptible to suggestions from other people, a tendency for wishful thinking, rigid beliefs and authoritarianism (Otto \& Featherman, 1975, p. 702). The feeling of alienation also triggers emotions which often lead the person to resolve this issue in a destructive manner: e.g. through addiction, rebellion, sickness, suicide, or creating communities with destructive characteristics (Biegasiewicz, 2011, p. 116). Taking away the ability of the imprisoned to contact their relatives 
is a negative phenomenon, as it is considered a factor of penitentiary recidivism. Researchers state that more visits by relatives to a prisoner means fewer arrests or subsequent imprisonments (Parsons \& Warner-Robbins, 2002, p. 7; Williams, Papadopoulou, Booth \& Ministry of Justice Analytical Services, 2012, p. 15).

According to both international ${ }^{1}$ and domestic laws,${ }^{2}$ keeping in contact with relatives from the outside is an inviolable right of the imprisoned. The implementation of those laws is dependent on the type of the penitentiary facility. ${ }^{3}$ The possible forms of contact with relatives and loved ones mentioned by the documents are visits, correspondence, phone calls, post parcels, money orders; and in some justified cases, if the director of the penitentiary agrees, other forms of communication (art. 105. $§ 1$ of the Executive Penal Code), such as instant messaging via the internet.

The frequency of the aforementioned forms of communication, and their potential censorship or supervision, is dependent on the type of penitentiary facility, as follows:

a) Persons serving their sentence at an open type of prison are allowed an unlimited number of visits, which can be supervised by the administrative staff of the prison (excluding conversations during the visits); no censorship by the administrative staff as regards correspondence; and no supervision of phone calls (art. 92 of the Executive Penal Code), which are made from a coin-box telephone with a frequency determined by the internal order of the penitentiary facility (§ 24. 1 Regulations...) (usually unlimited);

b) Persons serving their sentence at a half-open type of prison are allowed up to three visits per month, which are supervised; correspondence and phone calls may be supervised (art. 91 of the Executive

${ }^{1}$ For example: Committee of Ministers of the Council of Europe, Recommendation of the Committee of Ministers to member states on the European Prison Rules (adopted by the Committee of Ministers on 11 January 2006 at the 952 meeting of the Ministers' Deputies) recommends communication between the imprisoned and their families and other people via postal services and phone, as well as visits from such persons (art. 24).

${ }^{2}$ For example, the Act of 6 June 1997, Executive Penal Code [Polish Kodeks karny wykonawczy], Dz. U. [Journal of Laws] 1997 No. 90 item 557, in which communication with relatives is considered as one of the rights of the imprisoned person (art. 102).

3 The matter is governed by the Executive Penal Code and the Regulation of the Minister of Justice from 21 December 2016 on the regulations concerning organisation and order of the execution of a custodial sentence, Dz.U. [Journal of Laws] 2016, item 2231. 
Penal Code) (their frequency, as in the case of an open prison, is determined by the internal order of the facility);

c) Persons serving their sentence at a closed type of prison are allowed supervised visits, censored correspondence, and supervised phone calls, not more than once a day (art. 90 of the Executive Penal Code; $\S 16.4$ i $\S 24.1$. Regulations...); in the case of prisoners who pose a serious social risk or a safety risk for the facility, visits are supervised with enhanced security, and can occur in such a way that the visitor cannot come into direct contact with the prisoner (art. 88b of the Executive Penal Code).

Among the few exceptions to the aforementioned rules are the right to an additional monthly visit for juvenile offenders serving their sentence at closed and half-open prisons (art. 91a of the Executive Penal Code), and for prisoners with custody of a child of up to 15 years of age (art. 105a $\S 3$ of the Executive Penal Code).

Detailed regulations concerning the contact of prisoners with relatives are defined in the penitentiary facility's provisions regarding internal order. This governs the determination of days of the week and hours of the visits, days without visits, and the priority for visits.

Temporarily detained persons also have the right to sustain relationships with relatives. Standards regarding this right can be found in Recommendation Rec (2006) 13 of the Committee of Ministers to member states, on the use of remand in custody, the conditions in which it takes place, and the provision of safeguards against abuse; ${ }^{4}$ and also in the Act of 20 February 2015 on the amendment of the Penal Code, ${ }^{5}$ under which the complete ban on a temporarily detained person using a telephone by his cost was repealed.

While the laws regulating the organisation of incarcerated persons' contact with their relatives are clearly defined, little is known about the state of such contacts in Polish penitentiary facilities. However, Western researchers have for decades been dealing with the issue of contacts between prisoners and their relatives. According to Nigel Walker (1983, pp. 61-71), the number of visits and received correspondence from the wives of imprisoned men diminishes over time, and the seventh year of the sentence seems to be critical. Siennick (Siennick, Stewart \& Staff, 2014, p. 373) indicates that because of restricted contacts and the change in their form, married prisoners form a group who are particularly liable to undergo divorces while serving their

\footnotetext{
${ }^{4}$ Adopted by the Committee of Ministers on 27 September 2006.

${ }^{5}$ Dz.U. [Journal of Laws] 2015, item 396.
} 
sentence or shortly after. On the other hand, in regard to contacts between an imprisoned parent and their children, Western researchers came to the conclusion that in a state prison, the dominant form of contact was exchanging correspondence ( $70 \%$ of respondents). A smaller number of prisoners talked with their children on the telephone (53\%), and even fewer were visited by their children (42\%). In a federal prison, these percentages were $84 \%, 85 \%$ and 55\% respectively (Glaze \& Maruschak, 2010, p. 6). Similar results were acquired by Monika Badowska-Hodyr, as regards the population of imprisoned women in Poland and Czech Republic. According to her research, 75\% of the imprisoned mothers corresponded with their children, $68 \%$ talked with them on the phone, $47 \%$ of the mothers were visited by their children, and $3 \%$ used an online communicator (Badowska-Hodyr, 2017, p. 63).

However, there are no studies comparing the state of contacts between repeat criminals and persons serving their first sentence. This topic seems to be interesting enough to warrant research. It poses a question: Does penitentiary recidivism strengthen alienation, lessen contact with relatives, and limit the sources and forms of contacts?

\section{Methodology of the research}

The aim of the conducted research was to formulate an answer to the question: What is the structure of contacts between males serving their first sentence and their relatives, as well as between repeat criminals and their relatives? On that basis, is it possible to conclude that penitentiary recidivism is a factor in alienation and the lessening of such contacts?

Since the term 'structure of contacts with relatives' is quite wide, the following elements were chosen for research purposes:

- Having a least one source of contact in the outside world, or having none

- Having a source of contact (such as their mother, father, child, wife, partner, distant relatives, friends, acquaintances or other persons)

- Forms in which the imprisoned keeps in contact with his or her relatives

A survey study was used, with a specially prepared questionnaire. This consisted of several questions with answers to choose from, and was a part of a bigger project. The questions were used to gather data regarding socio-demographic characteristics of the survey participants, such as age, education, marital status, type of sentence, and number of stays in penitentiary isolation. 
Later, the participants were asked to choose from a table, to indicate which relatives they stay in contact with, and in what way.

The research was conducted in the period between January and March of 2019, among 556 males imprisoned in all possible types of prisons, that is:

- in a closed type prison in Goleniów, used for repeat criminals;

- in a prison in Stargard with closed and half-open units for males serving their first sentence;

- in half-open units at the Detention Centre in Szczecin;

- in a closed type prison in Nowogard, used for repeat criminals, and in the external unit of the same prison in Płoty, which is an open type prison.

Imprisoned males were asked to take part in the study. Recruitment of volunteers was performed by the penitentiary workers leaving leaflets in living cells. Potential participants were gathered into groups and moved into places designated by the prison management (e.g. common room of the living unit, meeting room, gym) where the researchers stated the aim and conditions of the study. Next, with the researchers present, participants filled in the questionnaires.

After preliminary assessment of the answers, around $15 \%$ of the questionnaires were rejected because of incomplete data. The analysis presented in this article is based on data from 478 imprisoned males. The results have been analysed and presented as a table with different categories. Analysis was performed using the Statistica 13.1 software (StatSoft).

\section{Results of the study}

The conducted study allowed the researchers to define the socio-demographic characteristics of the participants. Before being imprisoned, most of them lived in cities $(n=383 ; 80.1 \%)$. Their age was between $16-68$ years (the largest group among them were persons aged $31-40$ years, $n=184$; $38.0 \%)$, usually with primary $(\mathrm{n}=162,33.9 \%)$ or basic vocational education $(\mathrm{n}=168 ; 35.1 \%)$. There were slightly more persons who were in a relationship (usually informal, $\mathrm{n}=197 ; 41.2 \%$; there were fewer married persons, $\mathrm{n}=66 ; 13.8 \%$; in total, $55.0 \%$ of participants were in a relationship). The biggest group among the participants consisted of prisoners with a sentence of 3 to 5 years $(n=115 ; 24.0 \%)$. Ten prisoners were sentenced to life imprisonment. There were more repeat criminals $(\mathrm{n}=274 ; 57.3 \%)$ than persons serving their first sentence. 


\section{Contact with relatives}

The percentage of prisoners who maintained contact with at least one relative was high for both participants serving their first sentence and repeat criminals. The highest score was noted among prisoners who were imprisoned for the third time $(n=70 ; 98.6 \%)$ (table 1$)$. It was demonstrated that there are prisoners who have no contact with any relative outside of the prison ( $\mathrm{n}=40 ; 8.4 \%$ of all participants).

Table 1. Contact with at least one relative according to the numbers of stays in prison

\begin{tabular}{|c|c|c|c|c|c|c|c|c|c|c|}
\hline & \multicolumn{8}{|c|}{ NUMBER OF STAYS IN A PRISON } & \multirow{2}{*}{\multicolumn{2}{|c|}{$\begin{array}{c}\text { Total } \\
\mathrm{n}=478\end{array}$}} \\
\hline & \multicolumn{2}{|c|}{$\begin{array}{c}\text { First stay } \\
n=202\end{array}$} & \multicolumn{2}{|c|}{$\begin{array}{l}\text { Second stay } \\
\mathrm{n}=100\end{array}$} & \multicolumn{2}{|c|}{$\begin{array}{c}\text { Third stay } \\
\mathrm{n}=71\end{array}$} & \multicolumn{2}{|c|}{$\begin{array}{c}\text { Fourth or } \\
\text { subsequent stay } \\
n=105\end{array}$} & & \\
\hline & $\mathrm{N}$ & $\%$ & $\mathrm{~N}$ & $\%$ & $\mathrm{~N}$ & $\%$ & $\mathrm{~N}$ & $\%$ & $\mathrm{~N}$ & $\%$ \\
\hline $\begin{array}{c}\text { HAS } \\
\text { CONTACT }\end{array}$ & 187 & 92.6 & 90 & 90.0 & 70 & 98.6 & 91 & 86.7 & 438 & 91.6 \\
\hline $\begin{array}{l}\text { HAS NO } \\
\text { CONTACT }\end{array}$ & 15 & 7.4 & 10 & 10.0 & 1 & 1.4 & 14 & 13.3 & 40 & 8.4 \\
\hline
\end{tabular}

Source: Own study.

\section{Sources of contact with relatives}

Among both prisoners serving their first sentence and repeat criminals, their mother was the most frequent source of contact $(n=333 ; 69.7 \%$ of all survey participants; $\mathrm{n}=161 ; 79.7 \%$ of the prisoners serving their first sentence; and $\mathrm{n}=172 ; 62.3 \%$ of the repeat criminals). Other sources include distant relatives, friends and acquaintances (table 2). After comparing the data between the two most diverse subpopulations, separated on the basis of the number of stays in a prison (i.e. those who served their first sentence and those who had stayed in prison four or more times), it was noted that the percentage of participants declaring contact with the following relatives dropped: mother (from $79.7 \%$ to $53.3 \%$ ), father (from $43.6 \%$ to $24.8 \%$ ), wife (from $19.8 \%$ to $7.6 \%$ ) and - to a lesser degree - with members of extended family, friends and acquaintances. The percentage of participants who had 
contact with their partner was largely unchanged. However, the percentage of contacts with children had risen (from $36.1 \%$ to $40.9 \%$ ). The largest number of sources of contact per one participant was noted in the subpopulation of prisoners serving their first sentence (3.4), and the smallest amount among those prisoners who were in prison for at least the fourth time (2.7).

Table 2. Sources of contact according to the number of stays in prison

\begin{tabular}{|c|c|c|c|c|c|c|c|c|c|c|}
\hline \multirow{4}{*}{$\begin{array}{c}\text { SOURCE } \\
\text { OF CONTACT }\end{array}$} & \multicolumn{8}{|c|}{ Stays in prison } & \multirow{3}{*}{\multicolumn{2}{|c|}{$\begin{array}{c}\text { Total } \\
\text { participants } \\
\text { having } \\
\text { contact } \\
\text { with } \\
\text { a given } \\
\text { source }\end{array}$}} \\
\hline & \multicolumn{2}{|c|}{$\begin{array}{l}\text { First } \\
\text { stay }\end{array}$} & \multicolumn{2}{|c|}{$\begin{array}{l}\text { Second } \\
\text { stay }\end{array}$} & \multicolumn{2}{|c|}{$\begin{array}{l}\text { Third } \\
\text { stay }\end{array}$} & \multicolumn{2}{|c|}{$\begin{array}{l}\text { Fourth or } \\
\text { subsequent } \\
\text { stay }\end{array}$} & & \\
\hline & \multicolumn{8}{|c|}{$\begin{array}{l}\text { PARTICIPANTS HAVING CONTACT WITH } \\
\text { A GIVEN SOURCE }\end{array}$} & & \\
\hline & $\mathrm{N}$ & $\%$ & $\mathrm{~N}$ & $\%$ & $\mathrm{~N}$ & $\%$ & $\mathrm{~N}$ & $\%$ & $\mathrm{~N}$ & $\%$ \\
\hline MOTHER & 161 & 79.7 & 73 & 73.0 & 43 & 60.6 & 56 & 53.3 & 333 & 69.7 \\
\hline FATHER & 88 & 43.6 & 41 & 41.0 & 24 & 33.8 & 26 & 24.8 & 179 & 37.4 \\
\hline WIFE & 40 & 19.8 & 9 & 9.0 & 9 & 12.7 & 8 & 7.6 & 66 & 13.8 \\
\hline PARTNER & 73 & 36.1 & 44 & 44.0 & 28 & 39.4 & 38 & 36.2 & 183 & 38.3 \\
\hline CHILD & 73 & 36.1 & 40 & 40.0 & 23 & 32.4 & 43 & 40.9 & 179 & 37.4 \\
\hline $\begin{array}{c}\text { DISTANT } \\
\text { RELATIVES }\end{array}$ & 126 & 62.4 & 58 & 58.0 & 36 & 50.7 & 60 & 57.1 & 280 & 58.6 \\
\hline $\begin{array}{l}\text { FRIENDS AND } \\
\text { ACQUAINTANCES }\end{array}$ & 110 & 54.4 & 52 & 52.0 & 41 & 57.7 & 50 & 47.6 & 253 & 52.9 \\
\hline OTHER & 10 & 4.9 & 6 & 6.0 & 1 & 1.4 & 6 & 5.7 & 23 & 0.5 \\
\hline $\begin{array}{l}\text { Total sources of } \\
\text { contact }\end{array}$ & & & & & & & & & & \\
\hline $\begin{array}{l}\text { Sources of contact } \\
\text { per one participant }\end{array}$ & & & & 2 & & 9 & & & & \\
\hline
\end{tabular}

Source: Own study.

\section{Forms of contact with relatives}

The leading form of contact with all of the aforementioned categories of relatives was phone calls (Table 3). Participants of the study used this com- 
munication form to mostly contact their mothers $(n=305 ; 64.1 \%$ of all the participants). The second most used form was visits (usually by mothers), the third was letter correspondence. The highest percentage of prisoners declaring contact by phone was noted among prisoners serving their first sentence $(30.7 \%)$.

After comparing the data of those prisoners serving their first sentence with those who had stayed in prison four or more times, it was noted that the percentage of participants declaring contact through visits, letters and phone calls with their mothers, fathers, wives - and, less dynamically, members of extended family, as well as friends and acquaintances - was reduced. Particularly noticeable was the decrease in regard to wives (from $14.3 \%$ to $4.8 \%$ in the context of visits, from $12.4 \%$ to $3.8 \%$ in the context of correspondence, and from $17.8 \%$ to $5.7 \%$ in the context of phone calls). An increase has also been noted. The percentage of prisoners declaring contact with their children on the phone was higher among repeat criminals than among prisoners serving their first sentence ( $33.3 \%$ and $28.7 \%)$. A similar tendency was noted in regard to phone calls to a partner.

Table 3. Forms of contact for each source according to the number of stays in a prison

\begin{tabular}{|c|c|c|c|c|c|c|c|c|c|c|}
\hline \multirow{4}{*}{ 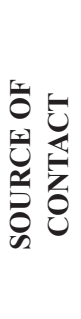 } & \multirow{4}{*}{$\begin{array}{l}\text { FORM OF } \\
\text { CONTACT }\end{array}$} & \multicolumn{8}{|c|}{ Stays in prison } & \multirow{4}{*}{ 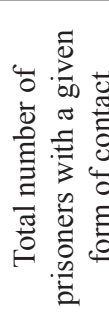 } \\
\hline & & \multicolumn{2}{|c|}{$\begin{array}{l}\text { First } \\
\text { stay }\end{array}$} & \multicolumn{2}{|c|}{ Second stay } & \multicolumn{2}{|c|}{$\begin{array}{l}\text { Third } \\
\text { stay }\end{array}$} & \multicolumn{2}{|c|}{$\begin{array}{l}\text { Fourth or } \\
\text { subsequent } \\
\text { stay }\end{array}$} & \\
\hline & & \multicolumn{8}{|c|}{$\begin{array}{l}\text { PARTICIPANTS WITH A GIVEN FORM } \\
\text { OF CONTACT }\end{array}$} & \\
\hline & & $\mathrm{N}$ & $\%$ & $\mathrm{~N}$ & $\%$ & $\mathrm{~N}$ & $\%$ & $\mathrm{~N}$ & $\%$ & \\
\hline \multirow{5}{*}{ 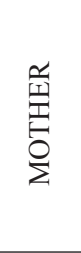 } & VISITS & 126 & 62.4 & 54 & 54.0 & 25 & 35.2 & 39 & 37.1 & 244 \\
\hline & LETTERS & 89 & 44.1 & 44 & 44.0 & 20 & 28.2 & 31 & 29.5 & 184 \\
\hline & PHONE & 147 & 72.8 & 66 & 66.0 & 40 & 56.3 & 52 & 49.5 & 305 \\
\hline & SKYPE & 6 & 3.0 & 8 & 8.0 & 2 & 3.0 & 3 & 1.9 & 19 \\
\hline & \multicolumn{9}{|c|}{ Contacts with mother in all forms } & 752 \\
\hline \multirow{5}{*}{ 省 } & VISITS & 63 & 31.2 & 32 & 32.0 & 11 & 15.5 & 16 & 15.2 & 122 \\
\hline & LETTERS & 40 & 19.8 & 22 & 22.0 & 9 & 12.7 & 16 & 15.2 & 87 \\
\hline & PHONE & 78 & 38.6 & 36 & 36.0 & 23 & 32.4 & 24 & 22.9 & 161 \\
\hline & SKYPE & 1 & 0.5 & 1 & 1.0 & 1 & 1.4 & 1 & 0.9 & 4 \\
\hline & \multicolumn{9}{|c|}{ Contacts with father in all forms } & 374 \\
\hline
\end{tabular}


Table 3. Forms of contact for each source according to the number of stays in a prison

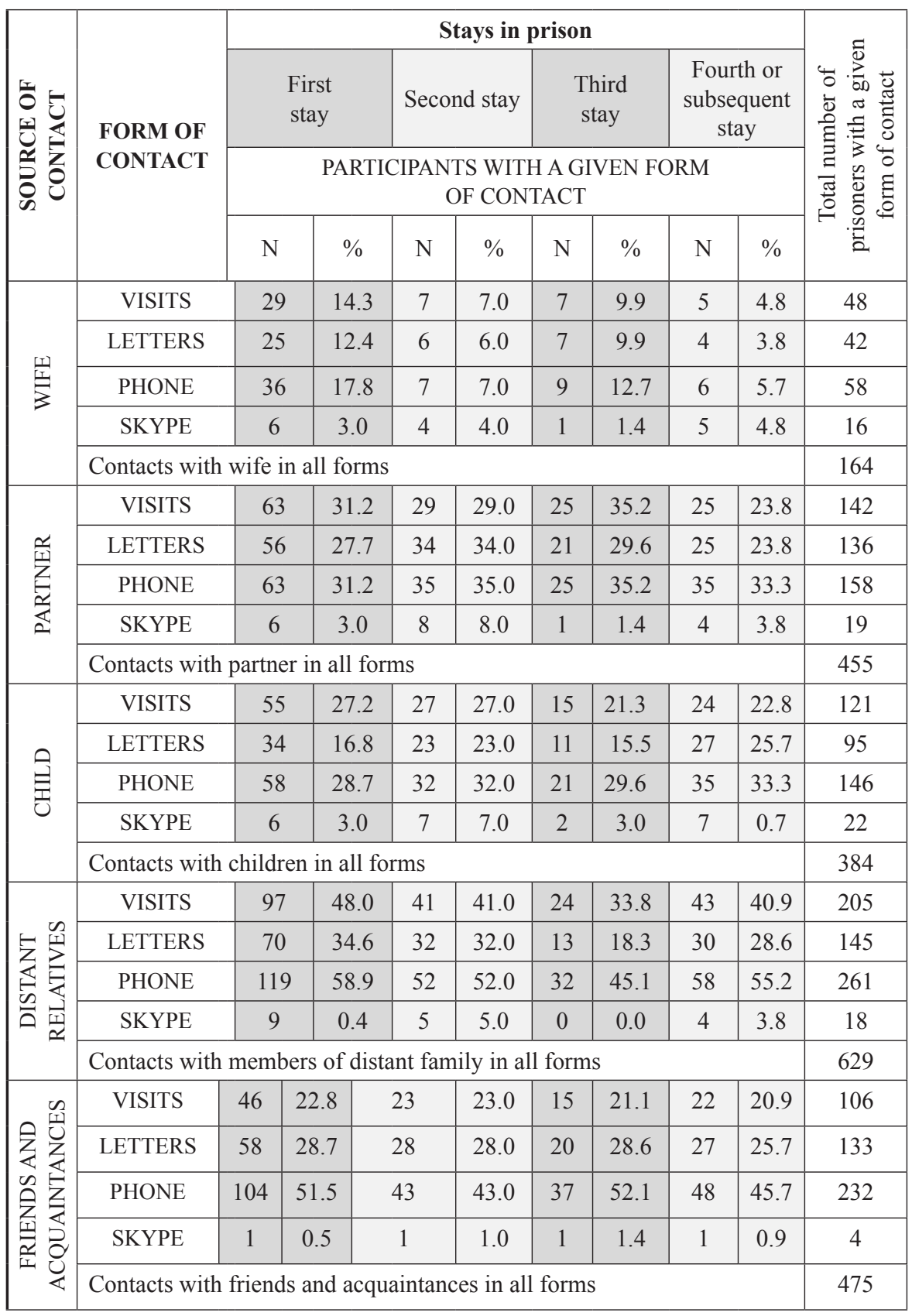


Table 3. Forms of contact for each source according to the number of stays in a prison

\begin{tabular}{|c|c|c|c|c|c|c|c|c|c|c|}
\hline \multirow{4}{*}{ 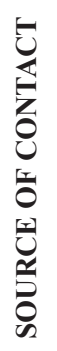 } & \multirow{4}{*}{$\begin{array}{l}\text { FORM OF } \\
\text { CONTACT }\end{array}$} & \multicolumn{8}{|c|}{ Stays in prison } & \multirow{4}{*}{ 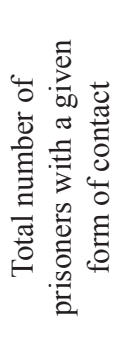 } \\
\hline & & \multicolumn{2}{|c|}{$\begin{array}{l}\text { First } \\
\text { stay }\end{array}$} & \multicolumn{2}{|c|}{ Second stay } & \multicolumn{2}{|c|}{$\begin{array}{l}\text { Third } \\
\text { stay }\end{array}$} & \multicolumn{2}{|c|}{$\begin{array}{l}\text { Fourth or } \\
\text { subsequent } \\
\text { stay }\end{array}$} & \\
\hline & & \multicolumn{8}{|c|}{$\begin{array}{l}\text { PARTICIPANTS WITH A GIVEN FORM } \\
\text { OF CONTACT }\end{array}$} & \\
\hline & & $\mathrm{N}$ & $\%$ & $\mathrm{~N}$ & $\%$ & $\mathrm{~N}$ & $\%$ & $\mathrm{~N}$ & $\%$ & \\
\hline \multirow{5}{*}{ 舀 } & VISITS & 1 & 0.5 & 1 & 1.0 & 0 & 0.0 & 1 & 0.9 & 3 \\
\hline & LETTERS & 8 & 4.0 & 7 & 7.0 & 1 & 1.4 & 5 & 4.8 & 21 \\
\hline & PHONE & 16 & 7.9 & 7 & 7.0 & 1 & 1.4 & 5 & 4.8 & 29 \\
\hline & SKYPE & 2 & 1.0 & 0 & 0.0 & 1 & 1.4 & 1 & 0.9 & 4 \\
\hline & \multicolumn{9}{|c|}{ Contacts with 'other' people in all forms } & 57 \\
\hline
\end{tabular}

Source: Own study.

\section{Discussion and conclusions}

The conducted study, which aimed to understand the structure of contacts between prisoners and their relatives, provides grounds for stating that most of the prisoners have contact with a person from the outside world. Most prisoners declared that they keep in touch with their mothers, usually in the form of phone calls (which were the most common form of communication between prisoners and their relatives).

The increase in number of stays in a prison usually led to a change in the structure of contacts, both in the number and composition of sources, as well as forms of realisation. It became apparent that the percentage of participants who had contact with at least one relative from the outside was larger among those serving their first sentence, in comparison to inmates who were being imprisoned for the fourth or a subsequent time. The largest percentage, however, was seen among those incarcerated for the third time almost all such prisoners had contact with a person in the outside world. A closer analysis showed a slightly different structure of the sources of contacts in this subpopulation, in comparison to the other groups. Among 
prisoners serving their third sentence, regarding who they kept in touch with, most mentioned their mothers, and after that their friends and acquaintances. In all other subpopulations the most numerous answer was mothers, then distant relatives, and lastly friends and acquaintances.

It was demonstrated that the most sources of contact per participant were seen in the group of persons serving their first sentence. This number of sources decreased in other groups, with the lowest number seen in the answers of repeat criminals.

As the number of stays in a penitentiary grew, the number of prisoners who declared contact with their mothers and fathers decreased; this can be attributed to the higher mortality among older generations. There were considerably fewer persons who stayed in touch with their wives among the repeat criminals than among prisoners serving their first sentence. This observed direction may result from the tendency of repeat criminals to use tactics such as 'allowing her to go', 'breaking up' and 'releasing' in regard to their partners; these have been described in the source literature. These tactics lead to severing the relationship, and allow men to build or recover their image as 'honourable', which controls the events outside the penitentiary (Szczepanik, 2017, pp. 196-197). The percentage of prisoners who maintained contact with their partners was relatively stable. It is worth considering that this result may be affected by other relationships that men have created during their stay in prison or during intervals between sentences. Those types of relations, despite their different statuses and duration, are often treated by prisoners as a way of treating another person in a possessive manner, as an antidote to the boredom in the prison, which excludes the possibility of creating a valuable and long-lasting relationship (Kowalczyk \& Adamowska, 2014, p. 247). An increase was also noted when comparing contacts between prisoners serving their first sentence and repeat criminals. The percentage of prisoners contacting their children was higher among repeat criminals than in the case of prisoners serving their first sentence; this increase was noted in the 'phone' and 'letters' categories.

The percentage of participants who declared contact in the form of visits, letters and phone calls with mothers, fathers, wives, distant relatives, and friends and acquaintances, was lower among those prisoners serving their fourth or subsequent sentence than for persons imprisoned for the first time (most frequently, this was the lowest of all percentages among the subpopulations categorized in the study). Particularly, the decreases in relation to wives stand out. A few increases have also been noted: the percentage of inmates declaring phone contact with a partner was higher among repeat 
criminals than among persons serving their first term. A similar tendency was seen in regard to phone contacts with a child. Among prisoners who declared that they maintain contact with their children, some realised this contact only by means of intermediate forms. There can be various reasons for children not visiting imprisoned parents; the most common one is hiding from the child the place where the parent is being held, or partially revealing the truth in regard to this topic (which, according to researchers, happens in the case of two-thirds of their children [Shaw, 1992, pp. 41-49]).

A comprehensive study has allowed identification of the quantitative characteristics of prisoners' contacts with their relatives. This creates a basis for stating that compared to persons serving their first sentence, among repeat criminals there is a smaller percentage of persons who stay in contact with at least one relative on the outside, and that repeat criminals have the smallest amount of sources and forms of contact, among the subpopulations distinguished in the study. It can be presupposed, then, that repeat offences correspond with alienation and a lack of contact with relatives outside. It cannot be stated, however, that the sources and forms of contacts with relatives decrease steadily with the number of stays in penitentiary isolation. Such a trend is not supported by the observation that the highest percentage of persons staying in touch with at least one relative on the outside is among prisoners serving their third sentence.

However, the relation between the feeling of alienation and lack of contact with relatives from the outside, on the basis of number of sources and forms of contact, is still a separate and unstudied issue. The feeling of alienation can occur as a consequence of situational alienation, but it is not inevitable. For example, there are situations where the inmate before his or her imprisonment had no ties with his or her own family, or compensates his or her lack of contacts by build relationships with other inmates. The above issues are suggested directions for further studies. It would be interesting to study these problems separately among female and male prisoners, to determine if sex and social roles influence the network of contacts and if they correlate with feeling of alienation. Those types of studies, however, are not easy to conduct, especially when using qualitative study techniques. Some of the problems would include the movement restrictions regarding visitors in prisons, including the researchers and the disproportion between male and female prisoner populations. 


\section{References}

Act of 20 February 2015 regarding change of act - Penal Code (Dz.U. [Journal of Laws] 2015, item 396).

Act of 6 June 1997 Executive Penal Code (Dz. U. [Journal of Laws] 1997, No. 90, item 557).

Badowska-Hodyr, M. (2017). Więź z rodziną i jej znaczenie w procesie inkluzji społecznej z perspektywy osadzonych kobiet odbywających kary długoterminowe. Probacja, III, 47-68.

Biegasiewicz, M. (2011). O próbach wykorzystania konstruktu alienacji do konceptualizacji procesu demoralizacji. Studia Psychologica, 11(1), 113-123.

Committee of Ministers of the Council of Europe, Recommendation of the Committee of Ministers to member states on the European Prison Rules (adopted by the Committee of Ministers on 11 January 2006 at the $952^{\text {nd }}$ meeting of the Ministers' Deputies).

Czerwińska-Jakimiuk, E. (2013). Poczucie alienacji u młodzieży a jego osobowościowe i społeczne korelaty. Normy, Dewiacje i Kontrola Społeczna, 357-373.

Glaze, L. E. \& Maruschak, L. M. (2010). Parents in Prison and Their Minor Children. Revised, Mar. 30, 1-25. https://www.bjs.gov/content/pub/pdf/pptmc.pdf, https://lemosandcrane.co.uk/resources/prisoners-childhood-familybackgrounds. pdf. [accessed: 14 sierpnia 2019].

Kmiecik-Baran, K. (1988). Poczucie osamotnienia. Charakterystyka zjawiska. Przeglad Psychologiczny, 4, 1079-1098.

Kmiecik-Baran, K. (1993). Poczucie alienacji. Treść i charakterystyka psychometryczna. Przeglad Psychologiczny, 4, 461-480.

Kmiecik-Baran, K. (1995). Poczucie alienacji: destruktywne i konstruktywne sposoby minimalizacji. Gdańsk: University of Gdańsk.

Korzeniowski, K. (1986). Ku pojęciu poczucia alienacji. Przeglad Psychologiczny, 2, 347-348.

Korzeniowski, K. (1990). O dwóch psychologicznych podejściach do problematyki alienacji. Próba syntezy. Przeglad Psychologiczny, 3(1), 121-143.

Kowalczyk, M. H. \& Adamowska, O. (2014). Rola związków partnerskich w resocjalizacji i wykonywaniu kary wobec skazanych długoterminowych. Rocznik Andragogiczny, 237-248. DOI: http://dx.doi.org/10.12775/RA.2014.017.

Łuczak, E. (2012). Sytuacje trudne w zakładach karnych i ich konsekwencje. Niepetnosprawność, 8, 40-47.

Niewiadomska, I. (2009). Psychospołeczne uwarunkowania alienacji społecznej by- 
łych więźniów. In S. Steuden \& K. Janowski (eds.), Psychospołeczne konteksty doświadczania straty (pp. 151-163). Lublin: Wydawnictwo KUL.

Niewiadomska, I. \& Chwaszcz, J. (2010). Jak skutecznie zapobiegać karierze przestępczej?. Lublin: Drukarnia Tekst Emilia Zonik i Wspólnicy.

Otto, L. B. \& Featherman, D. L. (1975). Social Structural and Psychological Antecedents of Self-estrangement and Powerlessness. American Sociological Review, 40(6), 701-719.

Parsons, M. L. \& Warner-Robbins, C. (2002). Factors that support women's successful transition to the community following jail/prison. Health Care for Women International, Jan. 23 (1), 6-18.

Recommendation Rec (2006) 13 of the Committee of Ministers to member states on the use of remand in custody, the conditions in which it takes place and the provision of safeguards against abuse. Ratified by Committee of Ministers on 27/09/2006.

Regulation of the Minister of Justice from 21 December 2016 on the regulations concerning organisation and order of the execution of a custodial sentence (Dz.U. [Journal of Laws] 2016, item 2231).

Seeman, M. (1959). On the meaning of alienation. American Sociological Review, 24(6), 783-791.

Shaw, R. (1992). Imprisoned fathers and the orphans of justice. In R. Shaw (ed.), Prisoners' children: What are the issues? (pp. 14-26), London: Routledge.

Siennick, S. E., Stewart, E. A. \& Staff, J. (2014). Explaining the association between incarceration and divorce. Criminology, 52(3), 371-398.

Szczepanik, R. (2017). Zarządzanie relacjami z partnerkami życiowymi przez mężczyzn odbywających karę pozbawienia wolności. Badania biograficzne z udziałem recydywistów. Przeglad Badań Edukacyjnych, 2(25), 183-200. DOI: http:// dx.doi.org/10.12775/PBE.2017.026.

Walker, N. (1983). Side-effects of incarceration. British Journal of Criminology, 23(1), 61-71.

Williams, K., Papadopoulou V., Booth N. \& Ministry of Justice Analytical Services (2012). Prisoners' Childhood and Family Backgrounds: Results from the Surveying Prisoner Crime Reduction (SPCR) Longitudinal Cohort Study of Prisoners. London: Ministry of Justice. 